\title{
Nodulation and mycorrhization of transgenic soybean after glyphosate application
}

\author{
Nodulação e micorrização de soja transgênica após \\ aplicação de glyphosate
}

\begin{abstract}
Aloisio Freitas Chagas Junior ${ }^{*}$; Marcelo Rodrigues dos Reis²; Gil Rodrigues dos Santos $^{1}$; Eduardo Andrea Lemus Erasmo ${ }^{1}$; Lillian França Borges Chagas ${ }^{3}$
\end{abstract}

\begin{abstract}
The sensitivity of nitrogen-fixing bacteria like Bradyrhizobium spp with in relation to glyphosate can be influenced by the concentration of the herbicide. This study aims to evaluate the effects of two formulations of glyphosate, in two application periods, on nodulation and mycorrhization in a soybean of variety RR P98Y11, using greenhouse, in pots with capacity of $4 \mathrm{~L}$ with savanna soils. Six treatments were utilized using Roundup Ultra and Roundup Original with one and two applications, witness without herbicide and witness only with mineral nitrogen, in a completely randomized design. Four evaluations were done, every 15 days, to determine the plant height, shoot and root dry weight, number of nodules, nodule dry weigh and mycorrhizae. It was observed an increase on the number of nodules, with the use of Roundup Ultra until 15 days after the first application. After this period, the witness only with inoculants showed a larger number of nodules. Roundup Ultra had positive influences on the dry weight of nodules, regardless the number of applications. There was no influence of glyphosate formulation considering the mycorrhizal colonization.
\end{abstract}

Key words: Bradyrhizobium, roundup, Glycine max

\section{Resumo}

A sensibilidade de bactérias fixadoras de nitrogênio como Bradyrhizobium spp. ao glyphosate pode ser influenciada pela concentração do herbicida. Assim, o objetivo neste trabalho foi avaliar os efeitos de duas formulações comerciais de glyphosate em aplicação única ou sequencial na nodulação e micorrização da soja RR P98Y11. O experimento foi desenvolvido em casa de vegetação em vasos com capacidade para $4 \mathrm{~L}$ com amostras de solo do cerrado. Foram utilizados seis tratamentos sendo Roundup original e Roundup ultra com uma e duas aplicações, testemunha sem herbicida e testemunha só com nitrogênio mineral, em delineamento inteiramente ao acaso. Foram feitas quatro avaliações, a cada 15 dias, determinando-se nodulação, micorrizas e peso de matéria seca. Com a utilização do Roundup ultra até os 15 DAA houve um aumento no número de nódulos, após este período a testemunha só com inoculante apresentou maior número de nódulos. O glyphosate teve influencia positiva quanto à massa seca de nódulos independente do número de aplicações e formulações. Quanto à colonização micorrízica não houve influencia de nenhuma das formulações de glyphosate.

Palavras-chave: Bradyrhizobium, roundup, Glycine max

\footnotetext{
${ }^{1}$ Profs. Adjuntos, Universidade Federal do Tocantins, UFT, Campus de Gurupi, Gurupi, TO, Brasil. E-mail: chagasjraf@uft.edu. br; gilrsan@uft.edu.br; erasmolemus@uft.edu.br

${ }^{2}$ Prof. Adjunto, Universidade Federal de Viçosa, UFV, Campus de Rio Paranaíba, Rio Paranaíba, MG, Brasil. E-mail: marceloreis@ ufv.br

${ }^{3}$ Discente de Doutorado em Produção Vegetal, UFT, Gurupi, TO, Brasil. E-mail: lillianfb@hotmail.com

${ }^{*}$ Author for correspondence
} 
The nitrogen biological fixation is one of the main biotic factors that contributes to the high production of soybean (Glycine max L.), being used through inoculation of selected strains of Bradyrhizobium japonicum and B. elkanii (HUNGRIA et al., 2005), with relevant emphasis on production in tropical and subtropical regions in Brazil (CRUZ et al., 2009).

The applying of nitrogen-fixing inoculants in soybean seeds is a usual practice in Brazilian soybeans production system. This operation has shown extremely positive results, contributing over $70 \%$ of the total $\mathrm{N}$ needed for this legume, leading Brazil to a significant savings in nitrogen fertilizers (HUNGRIA et al., 2005).

Another important effect of interaction between cultivated plants and soil microorganisms is the association of arbuscular mycorrhizal fungi (AMF). This association has been reported by several authors, which result in better nutrition and better supply of nutrients to plants, mainly phosphorus (SMITH et al., 2010). Furthermore, the supply of this nutrient to nitrogen-fixing bacteria is also improved. In the soybeans plant, beyond the direct benefits, there are positive effects on tripartite symbiosis legume, AFM and Bradyrizobium, resulting from better nutrition of $\mathrm{P}$ required for nodulation and $\mathrm{N}$ fixation (CARVALHO; MOREIRA, 2010).

In Brazil, the soybean crop stands out due to the high amount of herbicides used, since in its cultivation, weeds influence negatively the development (NEPOMUCENO et al., 2007; BOHM et al., 2011; LIMA et al., 2011). The large acceptance of soybean by farmers to these inputs is due to the high efficiency in weed control, the operating efficiency and the lower cost, when compared to other methods of control. The cultivation of transgenic soybeans resistant to glyphosate has been expanded throughout Brazil, representing about $80 \%$ of the cultivated area. However, the sensitivity of nitrogen-fixing bacteria like Bradyrhizobium spp. can be negatively influenced by the concentration of the glyphosate.
There are evidences that glyphosate can cause toxicity in strains of rhizobia, and often affects the soybean nodulation. These damages are reported in nodulation tests made in the laboratory where the herbicide is applied directly on the strains, as in field conditions (MALTY; SIQUEIRA; MOREIRA, 2006; BOHM ROMBALDI, 2010; REIS et al., 2010). These losses are due to the interference of the herbicide in the microsymbionts metabolism, in host plant or both. It is believed that the greater interference of these compounds occurs when they act on the biosynthesis of amino acids or metabolic pathways that are common to microorganisms and plants (SANTOS et al., 2006). Thus, the glyphosate application on crops that perform symbiosis with $\mathrm{AMF}$ and nitrogen-fixing bacteria may impair the efficiency of $\mathrm{P}$ absorption and assimilation of $\mathrm{N}$, respectively (MALTY; SIQUEIRA; MOREIRA, 2006).

Researches of glyphosate effects on the soybeanrhizobia symbiosis, as well as the effect on AMF, are still largely unknown, especially under conditions of climate and soil in the cerrado of the State of Tocantins. These studies can provide information about the tolerance or sensitivity of microorganisms to different formulations of glyphosate, which could be considered in the inoculants selection for best performance of the symbiosis process.

So, the objective of this study was to evaluate the effects of commercial formulations of glyphosate, on the processes of nodulation and natural AMF on inoculated soybean cultivar P98Y11RR with Bradyrhizobium japonicum.

The soybean cultivated was of the variety P98Y11RR early maturity, and tolerant to glyphosate. The soil was collected at the experimental station of UFT Campus Gurupi (1144'46,8' S 4903'07,4” $\mathrm{W})$, in areas where there had not been grown soybeans previously. The physical and chemical analysis of the ground had resulted in the following characteristics: $1,4 \mathrm{cmol}_{\mathrm{c}} \mathrm{dm}^{3}$ of Ca; $0,9 \mathrm{cmol}_{\mathrm{c}} \mathrm{dm}^{3}$ of $\mathrm{Mg} ; 0,1 \mathrm{cmol}_{\mathrm{c}} \mathrm{dm}^{3}$ of $\mathrm{K} ; 2,8 \mathrm{mg} \mathrm{dm}^{3}$ of P; 0,6 
$\mathrm{cmol}_{\mathrm{c}} \mathrm{dm}^{3}$ of Al; $8,3 \mathrm{cmol}_{\mathrm{c}} \mathrm{dm}^{3}$ of CEC; $5,0 \mathrm{cmol}_{\mathrm{c}}$ $\mathrm{dm}^{3}$ of $\mathrm{S} ; 61 \%$ of $\mathrm{V}$; $\mathrm{pH} 5,8$ on water; $1,7 \%$ of organic matter; texture of $79 \%, 5,0 \%$ e $16 \%$ of sand, silt and clay, respectively (EMBRAPA, 1997).

The seeds were inoculated with Bradyrhizobium japonicum with the strains Semia 5079 and 5080, with concentrations of $6 \times 10^{9}$ bacteria per $\mathrm{ml}$ of product. The inoculant was added to the seeds in the recommended commercial dose of $60 \mathrm{ml}$ to $50 \mathrm{~kg}$ of seed, the mixture being made of liquid inoculant on the seeds. After one hour was done directly planting seeds in the pots, using six seeds per pot. Seven days after germination thinning was done leaving two plants per pot with capacity of $4 \mathrm{~L}$.

The experimental design used was completely randomized with four replications. Six treatments were performed. The first treatment was an application of Roundup Original ${ }^{\circledR}$ (glyphosate isopropylamine salt $360 \mathrm{~g} \mathrm{~L}^{-1}$ acid equivalent), the second treatment was two applications of Roundup Original ${ }^{\circledR}$, the third treatment was an application of Roundup Ultra ${ }^{\circledR}$ (salt ammonium glyphosate with $\left.650 \mathrm{~g} \mathrm{~kg}^{-1}\right)$, the fourth was with two applications of Roundup Ultra ${ }^{\circledR}$, the fifth treatment was a control only to rhizobium inoculation and the sixth was a control without inoculation and without herbicide treatment with nitrogen in coverage (at 15 and 25 days after emergence in a dose of $40 \mathrm{~kg} \mathrm{~N}$ hectares ${ }^{-1}$ ). The evaluations were done at 15,30, 45 and 60 days after application (DAA), corresponding to stages of soybean V4, V9, R2 and R4.

The doses of Roundup Original were $3.0 \mathrm{~L} \mathrm{ha}^{-1}$ in the first application at 15 days after emergence (DAE) and $2.0 \mathrm{~L} \mathrm{ha}^{-1}$ for the second application at 30 DAE. For Roundup Ultra, were used $2.0 \mathrm{~L}$ $\mathrm{ha}^{-1}$ in the first application and $1.3 \mathrm{~L} \mathrm{ha}^{-1}$ in the second application. Herbicide application was done at 17:00 hours with $25^{\circ} \mathrm{C}, 55 \%$ air humidity, moist soil, wind speed of $1 \mathrm{~km} \mathrm{~h}^{-1}$. The spraying was made using a backpack sprayer pressurized with carbon dioxide $\left(\mathrm{CO}_{2}\right)$ equipped with a $\mathrm{XR}$ 11002 TEEJET nozzle and calibrated for volume application of $160 \mathrm{~L} \mathrm{ha}^{-1}$
At 15, 30, 45 and 60 days after application, the plants were harvested and divided into aerial part, roots and nodules. The drying was done in an oven for 72 hours at $105{ }^{\circ} \mathrm{C}$. Determined the dry mass of the aerial part (DMAP), of root (DMR), total (DMT), number of nodules (NN), nodule dry mass (MSN) and mycorrhizal colonization.

The mycorrhizal colonization was determined by the occurrence of arbuscular mycorrhizal fungi (AMF) on plant roots, through evaluation using the methodology described by Koske e Gema (1989). There was no inoculation with AMF, taking into consideration that the ground already had population of these fungi.

All data were statistically analyzed using variance $\mathrm{F}$ test, and the treatments average compared by the Scott Knott method at 5\% probability, using the software Sisvar 5.3.

The dry mass of aerial part (DMAP), of root (DMR) and total (DMT) were not affected in any treatment at 15 DAA (Table 1). At 30 DAA, a relevant difference was observed between treatments for DMAP, with the lowest mean for treatment with Roundup Original with one application, and occurring the same at 45 DAA $(p<0.05)$. At 60 DAA, the lowest means for DMAP were found for treatments with one and two applications of Roundup Ultra. Thus, there was negative effect on the use of DMAP with Roundup Original for evaluation periods at 30 and 45 DAA and Roundup Ultra at 60 DAA. Dvoranen et al. (2008) using glyphosate in different application kinds observed no influence of DMPA in soybean cultivars BRS 245 RR and BRS 247 RR, which is consistent with the expected selectivity of herbicides in relation to soybeans. In contrast, Reis et al. (2010) found negative effects of glyphosate on DMAP of a soybean cultivar BRS Favorite RR in a sequential and single application. It is suggested that the effects of glyphosate on DMAP are depending on the cultivar; although they are considered resistant to the product, there are variations in the level of resistance. 
For the DMR at 30 DAA, the highest average was found for treatment with one application of Roundup Ultra $(\mathrm{p}<0.05)$. At 45 DAA the lowest average was found for the control treatment with nitrogen, a result that is also repeated at 60 DAA. The both treatments of Roundup Ultra also showed the lowest average at 60 DAA (Table 1)

Table 1. Dry mass of aerial part (DMPA), root (DMR) and total (DMT) of soybean plants after application of the herbicides Roundup Original and Roundup Ultra ${ }^{1}$.

\begin{tabular}{|c|c|c|c|c|}
\hline $\begin{array}{l}\text { Herbicide } \\
\text { Treatments }\end{array}$ & $\begin{array}{c}\text { Rate } \\
\left(\mathrm{L} \mathrm{ha}^{-1}\right)\end{array}$ & $\begin{array}{c}\text { DMPA } \\
\left(\mathrm{g} \mathrm{vaso}^{-1}\right)\end{array}$ & $\begin{array}{c}\text { DMR } \\
\left(\mathrm{g} \mathrm{vaso}^{-1}\right)\end{array}$ & $\begin{array}{c}\text { DMT } \\
\left(\mathrm{g} \mathrm{vaso}^{-1}\right)\end{array}$ \\
\hline \multicolumn{5}{|c|}{$15 \mathrm{DAA}^{2}$} \\
\hline Roundup Original $1 \mathrm{X}^{(3)}$ & 3,0 & $4,8 \mathrm{a}$ & $1,6 \mathrm{a}$ & $6,4 \mathrm{a}$ \\
\hline Roundup Original $2 \mathrm{X}^{(4)}$ & $3,0 / 2,0$ & $5,0 \mathrm{a}$ & $1,8 \mathrm{a}$ & $6,8 \mathrm{a}$ \\
\hline Roundup Ultra 1X & 2,0 & $5,4 \mathrm{a}$ & $1,8 \mathrm{a}$ & $7,2 \mathrm{a}$ \\
\hline Roundup Ultra 2X & $2,0 / 1,3$ & $5,8 \mathrm{a}$ & $1,7 \mathrm{a}$ & $7,5 \mathrm{a}$ \\
\hline Inoculated Control & - & $5,0 \mathrm{a}$ & $1,5 \mathrm{a}$ & $6,5 \mathrm{a}$ \\
\hline Nitrogen Control & - & $4,8 \mathrm{a}$ & $1,2 \mathrm{a}$ & $6,0 \mathrm{a}$ \\
\hline $\mathrm{CV}(\%)^{(5)}$ & & 14,6 & 16,6 & 19,5 \\
\hline \multicolumn{5}{|c|}{$30 \mathrm{DAA}$} \\
\hline Roundup Original $1 \mathrm{X}$ & 3,0 & $9,0 \mathrm{~b}$ & $2,3 \mathrm{~b}$ & $11,3 \mathrm{~b}$ \\
\hline Roundup Original 2X & $3,0 / 2,0$ & $12,1 \mathrm{a}$ & $2,7 \mathrm{~b}$ & $14,8 \mathrm{a}$ \\
\hline Roundup Ultra $1 \mathrm{X}$ & 2,0 & $10,8 \mathrm{a}$ & $3,4 \mathrm{a}$ & $14,2 \mathrm{a}$ \\
\hline Roundup Ultra 2X & $2,0 / 1,3$ & $10,1 \mathrm{a}$ & $2,1 \mathrm{~b}$ & $12,1 \mathrm{~b}$ \\
\hline Inoculated Control & - & $12,6 \mathrm{a}$ & $2,7 \mathrm{~b}$ & $15,3 \mathrm{a}$ \\
\hline Nitrogen Control & - & $11,6 \mathrm{a}$ & $2,5 \mathrm{~b}$ & $14,1 \mathrm{a}$ \\
\hline $\mathrm{CV}(\%)$ & & 7,6 & 12,7 & 11,1 \\
\hline \multicolumn{5}{|c|}{45 DAA } \\
\hline Roundup Original $1 \mathrm{X}$ & 3,0 & $11,9 \mathrm{~b}$ & $2,9 \mathrm{a}$ & $14,8 \mathrm{~b}$ \\
\hline Roundup Original $2 \mathrm{X}$ & $3,0 / 2,0$ & $14,1 \mathrm{a}$ & $3,2 \mathrm{a}$ & $17,3 \mathrm{a}$ \\
\hline Roundup Ultra 1X & 2,0 & $13,6 \mathrm{a}$ & $2,7 \mathrm{a}$ & $16,3 \mathrm{a}$ \\
\hline Roundup Ultra 2X & $2,0 / 1,3$ & $13,5 \mathrm{a}$ & $2,4 \mathrm{a}$ & $15,9 \mathrm{a}$ \\
\hline Inoculated Control & - & $15,2 \mathrm{a}$ & $3,3 \mathrm{a}$ & $18,5 \mathrm{a}$ \\
\hline Nitrogen Control & - & $16,1 \mathrm{a}$ & $1,8 \mathrm{c}$ & $17,9 \mathrm{a}$ \\
\hline $\mathrm{CV}(\%)$ & & 16,9 & 23,4 & 22,2 \\
\hline \multicolumn{5}{|c|}{$60 \mathrm{DAA}$} \\
\hline Roundup Original $1 \mathrm{X}$ & 3,0 & $16,9 \mathrm{a}$ & $3,9 \mathrm{a}$ & $20,8 \mathrm{a}$ \\
\hline Roundup Original $2 \mathrm{X}$ & $3,0 / 2,0$ & $16,1 \mathrm{a}$ & $3,8 \mathrm{a}$ & $19,9 \mathrm{a}$ \\
\hline Roundup Ultra $1 \mathrm{X}$ & 2,0 & $13,9 \mathrm{~b}$ & $3,2 \mathrm{~b}$ & $17,1 \mathrm{~b}$ \\
\hline Roundup Ultra 2X & $2,0 / 1,3$ & $13,6 \mathrm{~b}$ & $3,1 \mathrm{~b}$ & $16,7 \mathrm{~b}$ \\
\hline Inoculated Control & - & $16,8 \mathrm{a}$ & $4,2 \mathrm{a}$ & $21,0 \mathrm{a}$ \\
\hline Nitrogen Control & - & $17,9 \mathrm{a}$ & $3,1 \mathrm{~b}$ & $21,0 \mathrm{a}$ \\
\hline $\mathrm{CV}(\%)$ & & 13,8 & 14,5 & 12,8 \\
\hline
\end{tabular}

${ }^{(1)}$ Means followed by same letter in columns do not differ by Scott-Knott test at $5 \%$. ${ }^{(2)} \mathrm{DAA}=$ Days after applying ${ }^{(3)} 1 \mathrm{X}$ is the same as one applying of herbicide. ${ }^{(4)} 2 \mathrm{X}$ is the same as two applying of herbicide. ${ }^{(5)}$ Coefficient of variation.

Source: Elaboration of the authors. 
The DMT at 30 DAA had the lowest means for treatment in one applying of Roundup Original, and also in treatments with Roundup Ultra in two applying. Even at 45 DAA treatment with Roundup Original in only one applying was significantly lower than other treatments. At 60 DAA, the lowest values for DMT were for treatments with Roundup Ultra in one and two applying (Table 1).

The number of nodules (NN) did not differ from the control at 15 and 60 DAA, considering one and two applying of Roundup Original (Figure 1A). However, at 30 DAA, there was about 70 and 22 nodules / plant, with two applications and single application of Roundup Original respectively, and the both results are superior to the control treatment. At 45 DAA, the NN was higher $(p<0.05)$ for the control followed by two applications of Roundup Original. In comparison, the Roundup Ultra and Roundup Original treatments had similar behavior, with emphasis on two applications at 30 DAA where was observed greater stimulus of nodulation - 101 nodules / plant (Figure 1B). However, at 45 DAA, the number of nodules at control treatment showed higher again $(p<0.05)$. Similar results were obtained in studies conducted in other countries, where it was found that glyphosate caused intoxication in strains of rhizobia, or harmed legume nodulation, including soybean (KING; PURCELL; VORIES, 2001).

The two commercial formulations of glyphosate had stimulated the formation of nodules at 30 DAA, but at 45 DAA were observed a deleterious effect. In plants, the total effect of glyphosate is noted after seven days of application, since the microorganisms also have the target enzyme of glyphosate EPSPs (5-enol piruvil shikimate 3-phosphate synthase). However, this effect was transient, because regardless of the Roundup formulation and method of application, there was a reduction of NN at 60 DAA, compared to 45 DAA. Several authors reported the adverse effect of glyphosate on the number of nodules of soybean plants
(ZABLOTOWICZ; REDDY, 2007; DVORANEN et al., 2008; BOHM; ROMBALDI, 2010). These results show that depending on the time of collection may have equal result (15 and 60 DAA) or different (30 and 45 DAA) of glyphosate application.

With glyphosate rates of up to $10 \mathrm{~L} \mathrm{ha}^{-1}$ applied before sowing, Malty, Siqueira e Moreira (2006) reported that glyphosate had no effect on nodulation of soybean grown at culture media and greenhouse. Thus, the additives in the formulation of agrochemicals can affect microorganisms and in some cases, even modify the agrochemicals effect.

For the Dry Mass of Nodules (DMN), Roundup Original applied twice favored the accumulation of $1.6 \mathrm{~g}$ of DMN / plant compared to control with 0.8 $\mathrm{g}$ of DMN / plant at $60 \mathrm{DAA}$ (Figure 1C). Roundup Ultra in one application favored the accumulation of more than $50 \%$ compared to control at 45 DAA but negatively affected the DMN at 60 DAA. On the other hand, we observed linear accumulation of DMN with two applications of Roundup Ultra, with the greatest accumulations of DMN at 30 and 60 DAA (Figure 1D).

Based on these results can be noted that the sequential application of glyphosate positively influenced the dry mass of nodules irrespective of the formulation used. Reports of glyphosate stimulating DMN were not found in the literature. Only had information saying that the glyphosate in a single application or sequential did not reduce the DMN in soybean plants grown in greenhouse (DVORANEN et al., 2008) and in sequential application in the field (REIS et al., 2010).

The mycorrhizal colonization was not affected by application of glyphosate regardless of the formulation, and the number of applications (one or two applications) up to 60 DAA (Figure 1E and 1F). Except at 45 DAA, where the single application of Roundup Original favored greater colonization compared to control (Figure 1E). 
Figure 1. Number of nodules (A and B), dry mass of nodules (DMN) (C and D) and mycorrhizal colonization (E and F) in soybean plants treated with Roundup Original and Roundup Ultra.
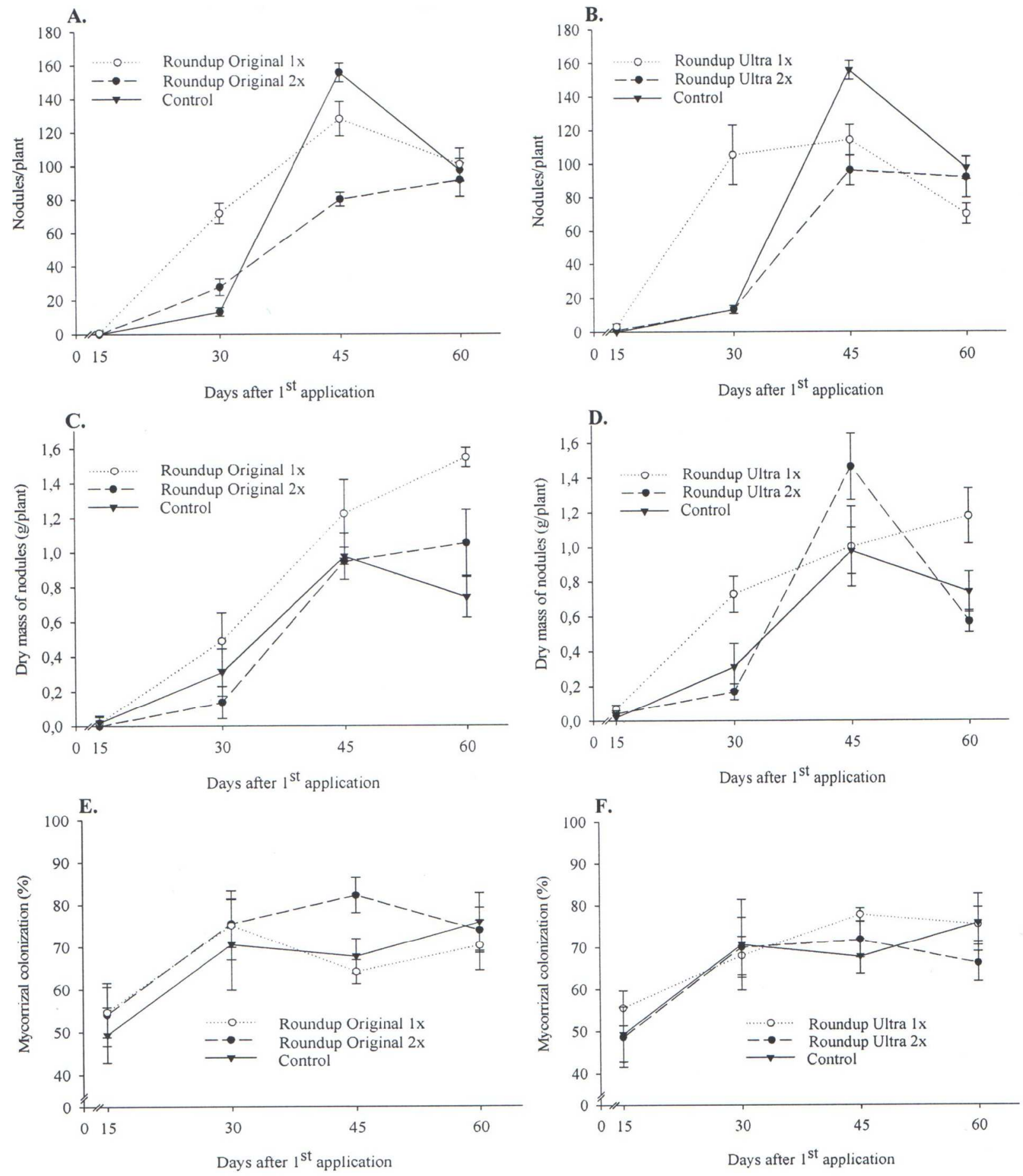

Source: Elaboration of the authors. 
The effects of glyphosate on mycorrhizal associations are not evident in soybeans (MALTY; SIQUEIRA; MOREIRA, 2006). In these studies, there were only one product application and the assay was conducted in vitro, that provides the maximum exposure to the product. These results corroborate those observed in this study that there is no influence obtained between applications of glyphosate and mycorrhizal associations even in two times.

The results suggest that there are relevant differences on the nodulation of soybean of variety P98Y11RR depending on the formulation and number of applications of glyphosate. The absence of significant effects on variables related to the biomass accumulation in aerial part and roots of plants indicates that the absence of symptoms of phytotoxicity of herbicides may underestimate their ability to affect symbiotic nitrogen fixation in soybean. However, the results for biomass and nodulation of inoculated treatments were similar to treatment with nitrogen, showing the potential for nitrogen fixation of strain used in the experiment, of great importance to production and productivity of soybean.

Commercial formulations of glyphosate, Roundup Original and Roundup Ultra, positively influence the nodulation of soybeans, especially in sequential applications. However, do not affect mycorrhizal colonization of soybean plants under these experimental conditions

\section{Acknowledgements}

The authors wish to thank CNPq and CAPES for financial assistance and UFT Campus Gurupi space, in the conduct of the experiment.

\section{References}

BOHM, G. B.; ROMBALDI, C. V. Efeito da transformação genética e da aplicação do glifosato na microbiota do solo, fixação biológica de nitrogênio, qualidade e segurança de grãos de soja geneticamente modificada. Ciência Rural, Santa Maria, v. 40, n. 1, p. 213-221, 2010.

BOHM, J. S.; SCHENEIDER, L.; CASTILHOS, L.; AGOSTINETTO, D.; ROMBALDI, C. V. Controle de plantas daninhas, biomassa e metabolismo microbiano do solo em função da aplicação de glifosato ou imazetapir na cultura da soja. Semina: Ciências Agrárias, Londrina, v. 32, n. 3, p. 919-930, 2011

CARVALHO, T. S.; MOREIRA, F. M. A. Simbiose tripartites: leguminosas, fungos micorrízicos e bactérias fixadoras de nitrogênio nodulíferas. In: SIQUEIRA, J. O.; SOUZA, F. A.; CARDOSO, E. J. B. N.; TSAI, S. M. (Org.). Micorrizas: 30 anos de pesquisas no Brasil. Lavras: UFLA, 2010. cap. 14, p. 383-413.

CRUZ, S. J. S.; OLIVEIRA, S. S. C.; CRUZ, S. C. S.; MADALENA, J. A. S.; CUNHA, J. L. X. L. Desempenho de três variedades de soja na região dos tabuleiros costeiros no Estado de Alagoas. Revista Caatinga, Mossoró, v. 22, n. 2, p. 195-199, 2009.

DVORANEN, E. C.; OLIVEIRA JUNIOR, R. S.; CONSTANTIN, J.; CAVALIERE, S. D.; BLAINSKI, E. GR Glycine max nodulation and growth under glyphosate, fluazifop-p-butyl and fomesafen aplication. Planta Daninha, Viçosa, v. 26, n. 3, p. 619-625, 2008.

EMPRESA BRASILEIRA DE PESQUISA AGROPECUÁRIA - EMBRAPA. Manual de métodos de análise de solo. 2. ed. Brasília: EMBRAPA. Produção de Informações. EMBRAPA Solos, 1997. 212 p.

HUNGRIA, M.; FRANCHINI, J. C.; CAMPO, R. J.; GRAHAM, P. H. The importance of nitrogen fixation to soybean cropping in South America. In: WERNER, D.; NEWTON, W. E. (Org.). Nitrogen fixation in agriculture: forestry ecology and environment. Dordrecht: Kluwer Academic Publishers, 2005. p. 25-42.

KING, C. A.; PURCELL, L. C.; VORIES, E. D. Plant growth and nitrogenase activity of glyphosate-tolerant soybean in response to foliar glyphosate applications. Agronomy Journal, Madison, v. 93, n. 1, p. 179-186, 2001.

KOSKE, R. E.; GEMA, J. N. A modified procedure for staining roots to detect VA mycorrhizas. Mycological Research, Manchester, v. 92, n. 4, p. 486-505, 1989. 
LIMA, D. B. C.; SILVA, A. G.; PROCÓPIO, S. O.; BARROSO, A. L. L.; DAN, H. A. Controle químico de plantas voluntárias de soja Roundup Ready® em diferentes estádios de desenvolvimento. Revista Caatinga, Mossoró, v. 24, n. 3, p. 64-70, 2011.

MALTY, J. D. S.; SIQUEIRA, J. O.; MOREIRA, F. M. S. Efeitos do glifosato sobre microrganismos simbiotróficos de soja, em meio de cultura e casa de vegetação. Pesquisa Agropecuária Brasileira, Brasília, v. 41, n. 2, p. 285-291, 2006.

NEPOMUCENO, M.; ALVES, P. L. C. A.; DIAS, T. C. S.; PAVANI, M. C. M. D. Períodos de interferência das plantas daninhas na cultura da soja nos sistemas de semeadura direta e convencional. Planta Daninha, Viçosa, v. 25, n. 1, p. 43-50, 2007.

REIS, M. R.; SILVA, A. A.; PEREIRA, J. L.; FREITAS, M. A. M.; COSTA, M. D.; SILVA, M. C. S.; SANTOS, E. A.; FRANÇA, A. C.; FERREIRA, G. L. Impacto do glyphosate associado com endossulfan e tebuconazole sobre microrganismos endossimbiontes da soja. Planta daninha, Viçosa, v. 28, n. 1, p. 113-121, 2010.
SANTOS, J. B.; SILVA, A. A.; COSTA, M. D.; JAKELAITIS, A.; VIVIAN, R.; SANTOS, E. A. Ação de herbicidas sobre o crescimento de estirpes de Rhizobium tropici. Planta Daninha, Viçosa, v. 24, n. 3, p. 457-465, 2006.

SMITH, S. E.; FACELLI, E.; POPE, S.; SMITH, F. A. Plant performance in stressful environments: interpreting new and established knowledge of the roles of arbuscular mycorrhizas. Plant and Soil, Berlin, v. 326, n. 1, p. 3-10, 2010.

ZABLOTOWICZ, R. M.; REDDY, K. N. Nitrogenase activity, nitrogen content, and yield responses to glyphosate in glyphosate-resistant soybean. Crop Protection, Maryland, v. 26, n. 3, p. 370-376, 2007. 